\title{
Ślady (nie)pamięci o Porajmosie. Kulturowa mapa romskiego holokaustu w Serbii i Chorwacji
}

Sabina Giergiel, Katarzyna Taczyńska

TEKSTY DRUGIE 2019, NR 2, S. 317-336

DOI: $10.18318 /$ td.2019.2.23 | ORCID: 0000-0002-5706-5679

$0000-0001-8540-4132$

\section{Wprowadzenie}

Bezpośrednim impulsem do napisania niniejszego tekstu stało się wydanie w 2015 roku powieści Nebojšy Lujanovicia zatytułowanej Oblak boje kože [Chmura w kolorze skóry]'. Utwór poświęcony został zagadnieniom romskiej zagłady ${ }^{2}$ oraz współczesnym mechanizmom stygmatyzacji tej grupy społecznej. Powieść chorwackiego pisarza jest jednym z niewielu tekstów powstałych w krajach byłej Jugosławii, który w sposób tak kompleksowy podejmuje problematykę romskiego holokaustu. Pamięć o zagładzie Romów jako społeczny i kulturowy konstrukt ma swoją własną historię, charakterystyczną dla danego kraju lub, szerzej, regionu, który zamieszkiwała ta społeczność. Powszechnie jednak holokaust Romów zarówno w historiografii, jak i w tekstach kultury przez wiele lat praktycznie nie pojawiał się lub funkcjonował

1 N. Lujanović Oblak boje kože, Fraktura, Zaprešić 2015.

2 Kwestie terminologii dotyczącej holokaustu Romów i pisowni z tym związanej rozwiniemy w dalszej części tekstu.

Sabina Giergiel - dr hab., prof. UO, pracuje w Instytucie Slawistyki UO. Autorka monografii: Obcość jako los. O prozie Borislava Pekicia (2008) i Ocalić pamięciq̨. Praktyki pamięci i zapominania we współczesnej prozie postjugosłowiańskiej (2012).

Katarzyna Taczyńska - dr, Instytut Slawistyki Zachodniej i Południowej UW. Autorka monografii Dowcip trwający dwa i pół roku. Obraz Nagiej Wyspy w serbskim dyskursie literackim i historycznym końca XX i początku XXI wieku (2016). 
na obrzeżach badań humanistycznych, stając się wątkiem towarzyszącym przede wszystkim rozważaniom o Zagładzie Żydów. Jak podkreśla Łukasz Kwadrans, Romowie - w odróżnieniu od Żydów - nie byli po wojnie traktowani w kategorii ofiar, wojna nie wpłynęła na zmianę społecznego obrazu (a więc stereotypów) Romów/Cyganów, którzy byli i pozostali na marginesie zainteresowania opinii publicznej ${ }^{3}$. Ponadto, jak trafnie zauważa Sławomir Kapralski, pamięć kulturowa w przypadku Romów nie wspiera się na charakterystycznych dla innych grup ramach instytucjonalnych (państwo, terytorium, pismo, religia), które decydują o podtrzymaniu pamięci o przeszłości ${ }^{4}$. Zaniedbania (a co za tym idzie nieobecność również w przestrzeni publicznej) w badaniach nad zagładą Romów istniejące praktycznie do lat 90. XX wieku mają swe źródło częściowo w czynnikach obiektywnych: doświadczenie ludobójstwa tej grupy jest bardzo zróżnicowane i jedynie w niewielkim stopniu udokumentowane ${ }^{5}$.

Z jednej strony milczenie wynikało zatem z zewnętrznej, społecznej dyskryminacji grupy i jej doświadczeń przez nie-Romów. Z drugiej zaś niesłyszalność romskiego głosu była pochodną specyfiki kodów kulturowych charakteryzujących tę grupę, które uniemożliwiały komunikowanie na temat traumatycznych doświadczeń, a tym samym nie pozwalały na zbudowanie spójnej narracji tworzącej część tożsamości. W kontekście pamięci (a właściwie jej braku) czy też niemej pamięci ${ }^{6}$ o romskiej zagładzie operacyjnie adekwatne wydaje się pojęcie dyskryminacji historycznej. W odróżnieniu jednak od definicji Lecha Nijakowskiego, od którego termin ten został zapożyczony, traktujemy go mniej rygorystycznie. Przede wszystkim jest tak dlatego, że opowieść o romskiej zagładzie nie stanowi „interpretacji alternatywnej” (jak podaje Nijakowski), wydaje się raczej „interpretacją równoległą”,

3 Ł. Kwadrans Romopedia. Encyklopedia wiedzy o Romach, Fundacja Integracji Społecznej Prom, Wrocław 2015, s. 188.

4 S. Kapralski Naród z popiołów. Pamięć zagłady a tożsamość Romów, Scholar, Warszawa 2012, S. 10.

5 Szczegółowy przegląd naukowych prac na temat Porajmosa wrazz listą świadectwźródłowych wytworzonych przez Romów zawiera artykuł Jerzego Dębskiego i Joanny Talewicz-Kwiatkowskiej Literatura i źródła, w: J. Dębski, J. Talewicz-Kwiatkowska Prześladowania i masowa zagłada Romów podczas II wojny światowej w świetle relacji i wspomnień, DiG, Stowarzyszenie Romów w Polsce, Warszawa 2007, s. 13-35. Lista zawiera teksty, które ukazywały się do połowy lat 90.

6 Określenie to zapożyczamy z tekstu Sławomira Kapralskiego Dlaczego warto uczyć o zagładzie Romów, w: Dlaczego należy uczyć o Holokauście?, red. J. Ambrosewicz-Jacobs, L. Hońdo, Wydawnictwo UJ, Instytut Europeistyki, Kraków 2005, s. 81. 
choć marginalizowaną7, w wyniku stosunków władzy i podporządkowania, w którym to głos podporządkowanych (nawet jeśli istnieje) jest praktycznie niesłyszalny. Przyjrzyjmy się bliżej zarówno przyczynom owej marginalizacji, jak i wieloletniej niedostatecznej - jak się wydaje - pamięci o Porajmosie wśród przedstawicieli grupy nim dotkniętej.

\section{Romska pamięć o Porajmosie}

Według części badaczy brak zainteresowania przeszłością wraz z jego konsekwencjami wynika ze specyfiki romskiej tożsamości. Naukowcy opowiadający się za substancjalnym jej charakterem uznają, że jest ona pozbawiona wymiaru historycznego, zaś sama pamięć Romów jest nietrwała, dlatego zostaje pozbawiona działań upamiętniających. Zwolennicy przekonania o relacyjnej tożsamości Romów nie odmawiają im pamięci, podkreślając jednocześnie, że dotyczy ona przede wszystkim stosunków społecznych, które tradycyjnie naznaczone są wrogością. Pamięć ta jednak nie jest przedmiotem głębszej refleksji i pielęgnacji. Kapralski natomiast zauważa, że ostatnie lata obfitują w próby zbudowania tożsamości na fundamencie historycznym ${ }^{8}$. Chociaż w innym tekście zaznacza, że próba ujęcia romskich dziejów w formę narracji historycznej jest obca ich kulturze, co w konsekwencji prowadzi do braku śladów pamięci o ofiarach na poziomie dyskursu grupy'.

Lech Mróz milczenie Romów o prześladowaniach wiąże z całkowitym załamaniem się tradycyjnej kultury romskiej (romanipen - kulturowa treść romskości), jaki został wymuszony przez warunki obozowe. Wówczas bowiem zostały zakwestionowane wszelkie regulacje dotyczące zasad tradycyjnej kultury romskiej. Wojna zatem doprowadziła do poczucia śmierci kulturowej tej społeczności, gdyż jedyne narzędzie, za pomocą którego mogłaby ona z doświadczeniem prześladowań się uporać, zostało naruszone, a wręcz zakwestionowane. Zatem Romów pozbawiono rodzaju ochrony, jaką dawało

7 L.M. Nijakowski O pojęciu dyskryminacji historycznej. Na przykładzie wspólnoty pamięci „ „dziadku w Wermahcie", w: Obszary i formy wykluczenia etnicznego w Polsce. Mniejszości narodowe, imigranci, uchodźcy, red. A. Jasińska-Kania, S. Łodziński, Scholar, Warszawa 2009, s. 105-122.

8 S. Kapralski Wpływ doświadczenia zagłady na współczesne tożsamości romskie, w: S. Kapralski, M. Martyniak, J. Talewicz-Kwiatkowska Głosy Pamięci 7. Romowie w KL Auschwitz, PMA-B, Oświęcim 2011, s. 37-38. Obszernie zagadnienie to Kapralski omawia w rozdziale drugim swojej książki Naród z popiołów..., s. 77-119.

9 S. Kapralski Dlaczego warto uczyć o zagładzie Romów..., s. 82. 
im wcześniej romanipen. Milczenie więc miałoby być wynikiem przekonania o braku kulturowej adekwatności między doświadczeniami jednostki a kulturą społeczności. Mówienie o zagładzie w tym kontekście mogłoby doprowadzić do wskazania na problematyczność tradycyjnych reguł porządkujących życie ${ }^{10}$. Tymczasem Kapralski, odwołując się do refleksji Mroza, podkreśla, że według części badaczy tradycyjna kultura romska przywołuje doświadczenie zagłady (np. w pieśniach), jednak ze względu na to, że obecne jest ono w tych elementach kultury, które są przeznaczone jedynie dla członków społeczności (dla nie-obcych), wiedza o nich nie wykracza poza grupę". Inni zaś (i tutaj polski socjolog i antropolog przywołuje stanowisko Elisabeth Filhol) uznają, że Romowie pamiętają o swej tragicznej przeszłości niejako wbrew tradycyjnej kulturze - za sprawą komunikacji z nie-Romami². Ponadto należy podkreślić, co akcentuje Dragoljub Acković, że Romowie są grupą, która praktycznie pozbawiona jest piśmiennych świadectw na temat własnej przeszłości, istniejące dokumenty są efektem pracy nie-Romów ${ }^{\mathbf{1 3}}$. Idąc tropem tego stwierdzenia, można by wskazać, że to inni opowiadają w imieniu społeczności romskiej, w wyniku interakcji przejmując rolę pośrednika. Doskonałym przykładem jest tutaj powieść Lujanovicia, która - jak podkreśla się w recenzjach i wywiadach z autorem - powstawała przez pięć lat, bowiem jej pisanie poprzedziły zakrojone na szeroką skalę badania terenowe i teoretyczne ${ }^{14}$. Jednak brak pisemnych świadectw nie jest związany jedynie z brakami w edukacji, które skutecznie utrudniają adekwatny przekaz treści. Badacze

10 L. Mróz Niepamięć nie jest zapominaniem. Cyganie-Romowie a Holokaust, „Przegląd Socjologiczny" 2000 t. XLIX, z. 2, , s. 107-108.

11 K. Bari The Holocaust in Gypsy Folk Poetry, w: Pharajimos: The Fate of the Roma During the Holocaust. International Debate Education Association, ed. J. Bársony, Á. Daróczi, International Debate Education Association, New York-Amsterdam 2008, cyt. za: S. Kapralski Wpływ doświadczenia zagłady..., s. 41.

12 E. Filhol The Internment of Gypsies in France (1940-1946): A Hidden Memory, w: Ethnic Identities in Dynamic Perspective: Proceedings of the 2002 Annual Meeting of the Gypsy Lore Society, ed. by S. Salo, C. Prònai, Gondolat, Budapest 2003, s. 13, cyt. za: tamże, s. 42.

13 D. Acković Romi u Beogradu, Rominterpress, Beograd 2009, s. 17.

14 V. Kulaš Nebojša Lujanović: Oblak boje kože "Moderna vremena" 29.03.2016, http://www.mvinfo.hr/clanak/nebojsa-lujanovic-oblak-boje-koze (05.03.18); J. Mlakić Romska sreća je, nažalost, incident, a ne pravilo, „Express” 08.08.2015, https://www.express.hr/life/romska-sreca-je-nazalost-incident-a-ne-pravilo-1948 (04.03.18); T. Borić U Hrvatskoj je glavni kriterij porijeklo, pa su drugačiji obilježeni, „nacional.hr” 14.08.2015, http://www.nacional.hr/nebojsa-lujanovic-u-hrvatskoj-je-glavni-kriterij-porijeklo-pa-su-drugaciji-obiljezeni/ (05.03.18). 
wskazują, że swoiste zapomnienie o romskiej zagładzie wynika z faktu, że przez powojenne dziesięciolecia społeczności Romów i Sinti nie wykształciły odpowiednio liczebnej elity intelektualnej, która skutecznie walczyłaby o pamięć o pomordowanych ${ }^{15}$. Wynika to zapewne $\mathrm{z}$ analogicznych przyczyn, jak te wskazane w kontekście milczenia o romskim holokauście, które zbiorczo wpisują się w przekonanie o dyskryminacji historycznej tej grupy ${ }^{16}$. Przekaz o zagładzie Romów pozostaje wciąż w znacznej mierze nierozpoznany i ukryty w relacjach, które nie doczekały się dotąd wypowiedzenia.

\section{Porajmos w perspektywie postjugosłowiańskiej}

W punkcie wyjścia opisu romskiego doświadczenia zagłady znajduje się kwestia języka, ściślej terminologii, która nie jest jednoznaczna nawet w przypadku nomenklatury międzynarodowych organizacji1". Wielu badaczy powołuje się w tym wypadku na konwencję przyjętą przez niektóre romskie instytucje, które zdecydowały, by słowo „holokaust” pisać małą literą, by w ten sposób odróżnić zagładę własnej społeczności od zagłady Żydów. Kapralski podkreśla, że konwencja precyzuje, iż „Romowie doświadczyli ludobójstwa zbliżonego do Holokaustu, ale nie identycznego z nim"18. W latach 90. romski lingwista i aktywista Ian Hancock wprowadził termin Porajmos (Baro Porrajmos) oznaczający 'pożarcie, pochłonięcie, trawienie'. Jednak ze względu na wywoływane przez niego konotacje w języku romani, w tym głównie kontekst przemocy na tle seksualnym, pojęcie budzi pewien sprzeciw i nie pozostaje neutralne ${ }^{19}$. Zdaniem Milovana Pisarriego, w języku serbskim terminu Porajmos właściwie się nie używa, a tylko sporadycznie się o nim wspomina ${ }^{20}$. W literaturze przedmiotu spotkać można ponadto zaproponowany przez romskich intelektualistów termin Samudaripen oznaczający 'całkowitą

15 J. Talewicz-Kwiatkowska Romowie i Sinti w KL Auschwitz, w: S. Kapralski, M. Martyniak, J. Talewicz-Kwiatkowska Głosy Pamięci 7..., s. 27.

16 N. Lengel-Krizman Prilog proučavanju terora u tzv. NDH: Sudbina Roma 1941-1945, "Časopis za suvremenu povijest" 1986 br. 1, s. 29.

17 Szerzej na ten temat zob. M. Pisarri Stradanje Roma u Srbiji za vreme Holokausta, Forum za primenjenu istoriju, Beograd 2014, s. 4. S. Kapralski Wpływ doświadczenia zagłady..., s. 38, przyp. 17. 
zagładę', którego po raz pierwszy użył Marcel Courthiade ${ }^{21}$. W niniejszym tekście synonimicznie używamy terminów romska zagłada i Porajmos. Do korzystania z drugiego terminu dodatkowo, w naszej ocenie, uprawnia nas to, że we wspomnianej powieści Lujanovicia, która interesuje nas tu najbardziej, autor odwołuje się do niego zarówno w sposób bezpośredni, jak i pośredni.

Na obszarze postjugosłowiańskim studia nad Porajmosem nie stanowią osobnej, wyspecjalizowanej dziedziny badań, choć oczywiście nie brakuje badaczy i opracowań, w których podejmowana jest problematyka z tego obszaru. Wśród nich ważne i wyjątkowe miejsce zajmują romscy intelektualiści i popularyzatorzy kultury Romów, tacy jak: Dragoljub Acković i Rajko Đurićn 2 . Jak wskazuje Milovan Pisarri, w Serbii zmiana perspektywy badawczej, w której zagłada Romów nie stanowiła już wątku pobocznego, dodatkowego, lecz stała się głównym przedmiotem namysłu, pojawiła się dopiero w pracy historyczki Danijeli Jovanović z 2006 roku, zatytułowanej Romi u Jevrejskom logoru Zemun 1941-1942 [Romowie w Żydowskim obozie Zemun 1941-1942, „Balkanski književni glasnik” 2006 nr 5]. Choć autorka nie korzysta w nim z nowych materiałów źródłowych, to jednak wyraźnie swoje zainteresowanie koncentruje na romskim doświadczeniu zagłady. Opracowanie Pisarriego z 2014 roku Stradanje Roma za vreme Holokausta [Cierpienia Romów w czasie Holokaustu] uznać należy za kontynuację pracy Jovanović. Na takiej pozycji sytuuje się również sam badacz, podkreślając we wstępie, że jego celem podobnie jak wcześniej Jovanović - jest włączenie do historii regionu badań nad specyfiką romskiej społeczności i problematyki holokaustu, których poznawanie i studiowanie nie może ograniczać się do działań autorstwa Romów ${ }^{23}$. Lokalna historia romskiej społeczności stała się również tematem prac badawczych socjologa Đokicy Jovanovicia, który rekonstruował losy Romów z okolic Niša w czasie II wojny światowej ${ }^{24}$. W rezultacie badań

Ł. Kwadrans Romopedia..., s. 188; M. Pisarri Stradanje Roma..., s. 4, przyp. 7.

Zob. np. D. Acković Romi u Beogradu...; tegoż Ašunen Romalen = Slušajte ljudi!, Rrominterpress, Beograd 1996; R. Đurić, A. Miletić Istorija holokausta Roma, Politika, Beograd 2008; R. Đurić Istorija romske književnosti, KOV, Vršac 2010; Р. Ђурић Историја холокауста Рома. Од антициганизма до логора смрти. Друштвене науке о Ромима у Србији. Зборника радова са трибина одржаних 2003. и 2004., red. Љ. Тадић, Г. Башић, SANU, Београд 2007, s. 5-22.

M. Pisarri Stradanje Roma..., s. 11.

Đ. Jovanović ...Čuo je da su Cigani streljani na Bubnju... Kultura zaborava ili Romi u Nišu u vreme II svetskog rata, w: Kultura sjećanja: 1941, red. S. Bosto, T. Cipek, O. Milosavljević, Disput, Zagreb 2008, s. 83-93. 
w 2007 roku powstał film dokumentarny Ovaj život, poklonjen mi je [To życie, zostało mi podarowane]. W tym kontekście wspomnieć trzeba również dokument z 2010 roku autorstwa dziennikarza Dragana Marinkovicia 11. decembar 1941. - masovno streljanje [11 grudnia 1941 - masowe rozstrzeliwania], który przedstawia historię zbrodni na Romach, do której doszło tytułowego dnia w miejscowości Leskovac. Nikła obecność Porajmosu w obrębie historiografii w Chorwacji rysuje się w tym kontekście bardzo wyraźnie. Jedyna monografia w całości poświęcona romskiej zagładzie to praca Narcisy Lengel-Krizman Genocid nad Romima. Jasenovac 1942 [Ludobójstwo Romów. Jasenovac 1942]25. Zatem waga pracy (również badawczej) wykonanej przez Lujanovicia - choć przełożona na język literatury - zyskuje dodatkowy, pozaartystyczny wymiar. Można zatem oczekiwać (lub przynajmniej mieć na to nadzieję), że powieść okaże się przełomowa dla tego problemowego impasu.

W kontekście praktyk komemoratywnych związanych z romską zagładą na terenie Chorwacji i Serbii, których podobnie jak w innych państwach Europy, jest stosunkowo niewiele, warto zwrócić uwagę na obchody różnych rocznic odwołujących się do historycznych wydarzeń. To one - poza śladami w formie upamiętniających tablic ${ }^{26}$ - stanowią widomy znak pamięci o przeszłości Romów na tych terenach. Pierwsza z dat to 2 sierpnia, czyli Międzynarodowy Dzień Pamięci o Zagładzie Romów przypominający o tragicznej nocy z 1944 roku, gdy w KL Auschwitz II-Birkenau zlikwidowano cygański obóz rodzinny, tzw. Zigeunerlager27. Na terenie Chorwacji uroczystości odbywają się w miejscowości Uštica, gdzie znajduje się 21 masowych grobów Romów na terytorium kompleksu obozowego Jasenovac ${ }^{28}$. Pierwsza komemoracja odbyła się

N. Lengel-Krizman Genocid nad Romima, Jasenovac 1942, Javna ustanova Spomen-područje Jasenovac, Jasenovac-Zagreb 2003. Książka stanowi rozszerzoną wersję artykułu z 1986 roku, uzupełnioną o materiały dokumentalne i listę ofiar.

Np. w Serbii jest to zamieszczona w 2006 roku w Belgradzie w miejscu obozu Topovske šupe płyta informująca, że stąd w 1941 roku Żydzi i Romowie byli wywożeni i rozstrzeliwani.

Więcej na ten temat: J. Talewicz-Kwiatkowska Romowie i Sinti..., s. 26.

M. Pisarri Stradanje Roma..., s. 29. Część Romów bezpośrednio po przybyciu do kompleksu obozowego Jasenovac była likwidowana, niektórzy z nich zaś początkowo trafiali właśnie do wsi Uštica (nazywanej „cygańskim obozem”), w której zamieszkali w opuszczonych przez Serbów domach. Kolejne grupy, które przybywały do obozu były umieszczane w leżącej na drugim (tj. bośniackim) brzegu rzeki Sawy (będącej w istocie granicą pomiędzy Chorwacją a Bośnią) miejscowości Gradina. N. Lengel-Krizman, Prilog proučavanju..., s. 37. Warto w tym miejscu zaznaczyć, że badacze stosują dwa zapisy miejscowości Uštica. W książce M. Pisarriego znajdujemy 
w 2012 roku w obecności przedstawicieli romskich organizacji oraz władz państwowych Chorwacji ${ }^{29}$. W Serbii - choć w dużo skromniejszym zakresie i z mniejszym rozgłosem - obchody odbywają się również 16 grudnia w Dniu Pamięci o Romach, którzy Zginęli w Czasie Drugiej Wojny Światowej. W tym dniu w 1942 roku Himmler wydał rozporządzenie dotyczące konieczności deportacji do obozów koncentracyjnych „mieszańców cygańskich, Cyganów-Roma, a także Cyganów pochodzenia bałkańskiego"30. Ponadto, z inicjatywy romskich stowarzyszeń historię romskich ofiar wspomina się również 11 grudnia, czyli w przywoływanym już tutaj dniu, gdy w miejscowości Leskovac doszło do masowych rozstrzeliwań Romów - wśród zabitych 310 cywilów było 293 Romów ${ }^{31}$. Komemoracja odbywa się przy pomniku poświęconym ofiarom tych wydarzeń.

Wątek romskiej zagłady pojawia się również w literaturze, jednak i tutaj zwykle ma charakter wątku pobocznego bądź też funkcjonuje w utworze na zasadzie wzmianki niewiele wnoszącej do centralnej problematyki danego tekstu. W przypadku literatury serbskiej zagadnienie to zostaje mimochodem przywoływane najczęściej w utworach skupiających się na losach Żydów unicestwionych w belgradzkim obozie Sajmište. Do niego bowiem trafiali również jugosłowiańscy Romowie, przede wszystkim kobiety i dzieci, które zajęły w nim tzw. Drugi Pawilon (zob. np. powieść Götz i Meyer Davida Albahariego) ${ }^{32}$. Niedostateczna obecność czy też brak wątków związanych z Porajmosem w literaturach postjugosłowiańskich może zaskakiwać. Zwłaszcza że badacze zajmujący się romską zagładą wyraźnie podkreślają, iż miejscem, w którym dopuszczano się szczególnego okrucieństwa wobec tej mniejszości, był obóz koncentracyjny Jasenovac (kompleks obozów z siedzibą główną w Jasenovacu), znajdujący się na terytorium istniejącego w latach 1941-1945

Uštice, N. Lengel- Krizman natomiast używa obu nazw Uštica/Uštice. My, w niniejszym tekście, konsekwentnie przywołujemy aktualną nazwę miejscowości, tj. Uštica.

M. Pisarri Stradanje Roma..., s. 5.

J. Talewicz-Kwiatkowska Romowie i Sinti..., s. 16.

M. Pisarri Stradanje Roma..., s. 5.

Wśród ponad sześciu tysięcy więźniów znalazło się około 600 romskich kobiet i dzieci. M. Koljanin Tokovi konačnog rešenja jevrejskog pitanja u Jugoslaviji, w: Seminar o Holokaustu. Zbornik radova, red. A. Frenkel, Jevrejska opština Novi Sad, Novi Sad 2009, s. 53. Koljanin w swojej fundamentalnej monografii poświęconej obozowi Sajmište poświęca Romom niewielki podrozdział: Romi u logoru na Sajmištu, w: tegoż Nemački logor na beogradskom Sajmištu 1941-1944, Institut za savremenu istoriju, Beograd 1992, s. 98-106. 
tzw. Niezależnego Państwa Chorwackiego (NDH, chorw. Nezavisna Država Hrvatska), w którym władzę sprawowała podporządkowana III Rzeszy chorwacka faszystowska organizacja ustaszów ${ }^{33}$. Dramat Romi u paklu Jasenovca [Romowie w piekle Jasenovaca] Bajrama Halitiego z 2012 roku, prezentowany w recenzjach jako „dzieło dokumentalne"34 - a więc w pewnym sensie bardziej niż tekst kultury traktowany jako rodzaj świadectwa, w którym zaciera się granica między fikcją a dokumentem - należy do rzadkich tekstów, których zasadnicza akcja rozgrywa się w obozie koncentracyjnym, a akcent został położony na perspektywę romskich ofiar.

Zdarza się również, że temat Porajmosa - czego przyczyną może być brak szczegółowych studiów w obrębie tej problematyki - staje się polem do nadużyć przy opisie, nadawaniu ram interpretacyjnych czy odczytywaniu poszczególnych tekstów kultury. Z taką sytuacją mamy do czynienia np. w powieści Dušana Savicia Porajmos z 2013 roku ${ }^{35}$, w której tytułowe doświadczenie staje się okazją do snucia fikcjonalnej dramatycznej opowieści o żydowskich i romskich mieszkańcach Sarajewa, którym - czasem w iście hollywoodzkim stylu - udaje się wyrwać z opresji śmierci. Można odnieść wrażenie, że historia Holokaustu i romskiej zagłady pełni w tekście funkcję wyłącznie tła dla niesamowitych narracji towarzyszących poszczególnym bohaterom. Obecność w tytule terminu Porajmos, który wprowadza granice, porządkujące lekturę tekstu, nie znajduje uzasadnienia i staje się po prostu nośną figurą retoryczną.

Po tym wstępnym rozeznaniu przejdźmy do analizy powieści Oblak boje kože, której będziemy się przyglądać jako wielowarstwowemu konstruktowi na temat romskiej pamięci. Strategię opowiadania w tekście porządkuje kilka kategorii. Pierwszą (i najbardziej ogólną) jest pamięć (a właściwie

L. Mróz Niepamięć nie jest zapominaniem..., s. 106. Kapralski twierdzi, że w Jasenovacu „liczba romskich ofiar przewyższyła najprawdopodobniej liczbę Romów zamordowanych w Auschwitz", S. Kapralski Naród z popiołów..., s. 139. Por. A. Morawiec, Literatura polska wobec ludobójstwa. Rekonesans, Wydawnictwo Uniwersytetu Łódzkiego, Łódź 2018, s. 300.Należy podkreślić, że badacze nie są zgodni co do liczby romskich ofiar zamordowanych w obozie. Liczby wahają się od 25000 do 80 ooo. Podajemy za: S. Kapralski, Naród z popiołów..., s. 162. Zob. też A. Korb Ustaša Mas Violence Against Gypsies in Croatia, 1941-1942, w: The Nazi Genocide of the Roma: Reassessment and Commemoration, red. A. Weiss-Wendt, Berghahn Books, New York 2013, s. 72-95. Iz recenzije mr Milice Lilić Jeftimijević, w: B. Haliti Romi u paklu Jasenovca, Beoknjiga, Beograd 2012, s. 139; Iz recenzije Miloša Markovića, w: B. Haliti Romi u paklu..., s. 143. 
jej brak) o ludobójstwie Romów. Dla jej zobrazowania Lujanović wykorzystuje zarówno przestrzenny, jak i temporalny motyw przemieszczania się. Drugim kluczowym w naszym odczytaniu pojęciem jest sam termin Porajmos, którego prymarne znaczenie jest w powieści wielokrotnie przywoływane i eksploatowane na kilku - wzajemnie przenikających się - poziomach. Obie kategorie tworzą punkty węzłowe prezentowanej interpretacji powieści.

\section{Determinanty działań: ruch, wykluczenie i strach}

Klamrą spinającą powieść Lujanovicia jest motyw przemieszczania się głównego bohatera, młodego Roma - Enisa. Jego wędrówka jest aktem wymuszonym, czytelnik wie, że mężczyzna ucieka z Zagrzebia i zmierza w kierunku rodzinnej miejscowości w Bośni. Przyczyny działań Enisa nie są początkowo znane, odbiorca wie tylko, że zdarzyło się coś, co zmusiło protagonistę do podjęcia takiego kroku. Przymus pozostawania w nieustannym ruchu jest jednym z częstych tematów opisujących nomadyczną egzystencję Romów. Jednak w powieści nie wynika on ze specyfiki ich życia, ale - co już zostało zaznaczone - stanowi rezultat okoliczności zewnętrznych. Enis w trakcie podróży spotyka innych Romów, których migracja z Bośni do Chorwacji z kolei jest umotywowana poczuciem zbliżającej się wojny (jugosłowiańska wojna domowa lat 9o. XX wieku). Zarówno Enis, jak i grupa Romów przebywają zatem tę samą drogę, jednak w odwrotnych kierunkach, z jednej strony w poszukiwaniu bezpieczeństwa, z drugiej uciekając przed cierpieniem. Tę paralelę ruchu można odczytywać jako symbol daremności ich wysiłków. Jałowość działań wpisuje się w wieloletnią czy wręcz wielowiekową powtarzalność praktyk migracyjnych u Romów, konieczność przemieszczania się, która niezmiennie wychodzi od wykluczenia lub do niego prowadzi.

Utwór ma budowę szkatułkową, współczesna trzecioosobowa historia Enisa łączy się z opowieścią (zapisaną inną od narracji głównej czcionką) Ramadana, Roma, którego monolog stanowi drugą warstwę powieści. Ramadan w tym funkcjonującym niczym świadectwo wyznaniu pojawia się jako umierający więzień obozu koncentracyjnego w Auschwitz. Również ta historia determinowana jest przez ruch, a mianowicie snuta jest podczas próby ucieczki, podjętej tuż przed ostateczną likwidacją obozu cygańskiego.

Rytm działań bohaterów jest wyznaczany ruchem w perspektywie geograficznej i terytorialnej i łączy się bezpośrednio na planie fabularnym 
z perspektywą przemieszczania się na poziomie czasowym: w powieści czytamy o wydarzeniach współczesnych i czasach II wojny światowej, jak również o okresie przedwojennym, który jednak jest jedynie wzmiankowany, stanowiąc swoiste preludium do opowieści o ludobójstwie podczas wojny. Wydaje się, że Lujanović (wykorzystując dwie perspektywy czasowe i koncentrując swą uwagę na kilku przestrzeniach) wyraźnie wskazuje na powtarzalność mechanizmów wykluczania, generowanych przez niechęć do Romów, których kulminacją była eksterminacja w czasie II wojny światowej. Powieść chorwackiego autora eksploatuje zatem znaczące dla tożsamości romskiej czasoprzestrzenie. To wokół nich (konkretnych miejsc i momentów historycznych) koncentrują się sensy snutej przez Lujanovicia opowieści.

Drugim, wiążącym dwie perspektywy czasowe, motywem - sytuującym się częściowo ponad światem przedstawionym - jest odwieczny strach towarzyszący Romom oraz powiązana z nim, a podejmowana na różne sposoby próba wyrwania się, uwolnienia się od losu, jaki w związku z pochodzeniem zostaje im przeznaczony. Lujanović opowiada o skłonności człowieka do odsuwania na margines tego, co nie wpasowuje się w zakładaną wersję ładu. A to $\mathrm{z}$ kolei zbieżne jest z przekonaniami części badaczy tożsamości romskiej (zwolenników teorii procesualnej), jak również działaczy wywodzących się z tej społeczności. Kwestionują oni pogląd, że Romowie są ludem bez historii, i wskazują, że pewne stygmatyzujące mechanizmy historyczne są powtarzalne, to one tworzą logikę historii tej społeczności, której kulminacją była podjęta w czasie II wojny światowej próba eksterminacji Romów. W ich mniemaniu współczesne akty dyskryminacji stanowią kontynuację dawnych prześladowań oraz reprodukcję mechanizmów kształtujących romską historię $e^{36}$. Lujanović nawiązuje do tego przekonania, opisując współczesne getto, które powstaje na przedmieściach Zagrzebia po - jak się na końcu powieści dowiadujemy - niesprawiedliwym oskarżeniu Enisa o podpalenie baru. Plinarsko naselje - oddalona od centrum i zamieszkana przez Romów dzielnica chorwackiej stolicy - staje się miejscem, z którego nie ma wyjścia. Jest przestrzenią, którą nadzorują żądni zemsty mieszkańcy miasta, otoczoną dla wzmocnienia izolacji drutem kolczastym, co w sposób jednoznaczny nawiązuje do rzeczywistości obozowej. Poczucie pozostawania w sytuacji bez wyjścia potęguje fakt, że społeczność romska została realnie odcięta od świata: wyprawa do najbliższych sklepów połączona jest z przygotowywaniem szczegółowego planu, którego celem jest uniknięcie spotkania ze 
„strażnikami”, porządnymi obywatelami, którzy w swoim mniemaniu jedynie bronią miasta przed zagrożeniem.

Cykliczność dramatycznych wydarzeń i nieusuwalne piętno determinujące los romskiej społeczności intensyfikuje dodatkowo nadciągająca wojna domowa w Jugosławii. Widmo konfliktu nakazuje Romom po raz kolejny pakować swój dobytek i ruszyć w poszukiwaniu lepszego miejsca do życia, gdyż to oni w sposób szczególny narażeni są na szykany i represje. Jednocześnie powtarzalność losu tej grupy społecznej staje się pośrednim dowodem na to, że każda, kolektywna czy indywidualna, próba wyrwania się z przypisanej roli skazana jest na niepowodzenie. Nieskuteczność na tym polu obserwujemy również na przykładzie działań pojedynczych bohaterów. Zarówno Enis, jak i jego siostra Sanda próbują zmienić swój los i uwolnić się od stygmatu, jaki wiąże się z ich pochodzeniem. Enis robi to dość nieudolnie, próbując zjednać sobie nieromskich przyjaciół swoją uległością i podporządkowaniem. Jego siostra zaś (której łatwiej wtopić się w nieromskie otoczenie, jej wygląd bowiem nie zdradza jej przynależności) ucieka od przypisanej roli, podejmując studia i za wszelką cenę starając się ukryć swe pochodzenie. Jak się jednak ostatecznie okazuje, wszelkie próby wyzwolenia się od piętna skazane są na porażkę.

\section{Mapa pamięci romskiej zagłady}

Rzeczywistość zilustrowana w powieści została bogato wyposażona w wiele faktów związanych z tematem romskiej zagłady. Można powiedzieć, że kształt świata przedstawionego tworzą różne historyczne wydarzenia i pozostające z nimi w korelacji miejsca, które wyznaczają kluczowe punkty dyskursu historycznego na temat Porajmosa. Lujanović przede wszystkim przywołuje dwa, najbardziej znaczące dla romskiej zagłady toponimy, a mianowicie Jasenovac i Auschwitz. Oprócz nich zostają również literacko opracowane takie wydarzenia, jak: strajk w obozie Dachau czy bunt Romów w Auschwitz, który uniemożliwił pierwszą planowaną eksterminację tej grupy. Mamy więc Jasenovac, Auschwitz, Dachau oraz wspomniane wcześniej przez nas miejscowości Uštica i Gradina. Ponadto w powieści przywołany zostaje austriacki kraj związkowy Burgerland, zamieszkany w okresie międzywojennym przez większość austriackich Romów. W kontekście fabuły znaczenia nabiera również rzeczna granica między Chorwacją a Bośnią, przestrzeń nie tylko oddzielająca dziś dwa państwa, ale teren szczególnie naznaczony zagładą (obóz Jasenovac). Lujanović zatem zdaje się kreślić mapę cierpienia Romów, będącą 
jednocześnie mapą niepamięci o zagładzie ${ }^{37}$. Główne punkty tej mapy wyznaczają konkretne, realnie istniejące miejsca odsyłające do tematu w sposób bezpośredni, między nimi istnieje silny związek w postaci śladów/znaków, które pośrednio przypominają o przeszłości. Całość tworzy swoisty układ, w którym wyróżnić można punkty centralne i peryferyjne oraz relacyjną łączność między nimi.

Warto zwrócić uwagę, że autor w wywiadach deklaruje, iż jego powieść może być czytana nie tylko jako utwór o dyskryminacji mniejszości romskiej, ale również jako tekst o losie każdej inności ${ }^{38}$. W tym kontekście znaczące wydaje się umieszczenie współczesnej akcji powieści tuż przed wybuchem wojny domowej w Jugosławii. Sytuacja konfliktu determinuje kolejne wędrówki ludności (nie tylko romskiej) zamieszkującej te tereny. Ponownie dochodzą tu do głosu przestrzeń i topografia, które wchodzą w relacje z człowiekiem zarówno cierpiącym, jak i zadającym cierpienie. Ten wątek zostaje w powieści jedynie zasygnalizowany, ale warto go tutaj przywołać, wskazuje bowiem na fakt wielokrotnego eksploatowania przez Lujanovicia kategorii przestrzennych. Chodzi mianowicie o rozmowy toczące się między pułkownikiem Jugosłowiańskiej Armii, a jego kierowcą o imieniu Fabo (ojciec Enisa), które skoncentrowane są wokół poszukiwań w Bośni, w pobliżu konkretnych miejscowości (Bihać, Brčko, Bosanki Šamac, Goražde, Drventa) opuszczonych, odosobnionych, a jednocześnie mogących pomieścić setki ludzi, budynków (Fabo wymienia w tym kontekście: magazyn wojskowy, fabrykę, starą cementownię). Lujanović wykorzystuje tu nazwy miejscowości, w których - w okresie poprzedzającym wybuch wojny domowej w Jugosławii - mieszkali przedstawiciele dwóch lub trzech grup etnicznych, ale w których większość stanowili Muzułmanie. Podpisany w 1995 roku pokój przeorientował zarówno skład demograficzny Bośni, jak i na nowo wyznaczył granice. Autor w powieści pośrednio zapowiada powstanie w latach 90. obozów koncentracyjnych, których działanie - podobnie jak w czasach II wojny światowej - podporządkowane jest idei etnicznego czyszczenia terenu. Obóz koncentracyjny powraca więc jako metafora bałkańskiej rzeczywistości, dla której ten twór stał się kluczową kategorią obrazującą XX-wieczne wydarzenia w regionie. Przypomnieć w tym miejscu można esej serbskiej pisarki Mariji Knežević Obóz jako metafora, w którym życie w regionie Bałkanów w czasie

Pomnik upamiętniający romskie ofiary holokaustu w Berlinie został odsłonięty dopiero 24 października 2012 roku. Zob. np. M. Pisarri Stradanje Roma..., s. 5. 
wojny zostało porównane do „abstrakcyjnego poczucia obozowej niewoli”, do przebywania w obozie otoczonym niewidocznym drutem kolczastym ${ }^{39}$.

\section{W kręgu zagłady}

Obóz Jasenovac pojawia się w książce w trakcie ucieczki Enisa do rodzinnej Bośni. Podczas wyczerpującej podróży, przebywając na granicy snu i jawy, bohater znajduje się jakby w równoległym świecie, w którym najpierw widzi maszerującą kolumnę duchów, a następnie stosy ciał. Jego wędrówka przez granicę chorwacko-bośniacką prowadzi obok miejscowości Nova Gradina i wsi Uštica. Przypomnijmy, że wieś Uštica jest niezwykle znacząca dla pamięci o zagładzie Romów, ze względu na obecność masowych grobów Romów, o czym już pisałyśmy ${ }^{\mathbf{4 0}}$. Narcisa Lengel-Krizman wskazuje zaś, że Gradina stanowi jedno z największych miejsc straceń na terytorium obozu Jasenovac, w którym tracili życie nie tylko Romowie, ale i przedstawiciele innych grup etnicznych ${ }^{41}$. Ta graniczna przestrzeń, tak niezwykle mocno naznaczona cierpieniem jest w powieści Lujanovicia terytorium, na którym słyszalne są głosy tych, którym głos odebrano. To za pośrednictwem bohatera utworu czytelnik obcuje z opowieściami, które chcą zostać zapisane i zapamiętane ${ }^{\mathbf{4 2}}$. Omawiany tutaj fragment obfituje w słowa, swoiste symbole jednoznacznie kojarzone zarówno z niezawinionym cierpieniem, jak i z topiką holokaustową: zabite dzieci, uderzenia, (za)kopanie, przysypanie, jamy, przemieszanie ciał i członków, stosy martwych. W tym fragmencie pobrzmiewa ponadto apel o oddanie sprawiedliwości niewinnym, ponowne ustanowienie porządku oraz o pamięć: „Ktoś musi nas odkopać, nas sparować. Kość z kością. Ktoś musi uporządkować nasz świat pod ziemią"43. Autor niezwykle sugestywnie opisuje sekwencję przybycia więźniów na miejsce. To właśnie obrazy z maja

40 Љ. Коко Значај документације о страданју Рома у другом светском рату, w: Прва међународна конференција Холокауст над Србима, Јеврејима и Ромима у другом светском рату. Зборник радова, red. В. Вученовић, В. Соловјов, Е. Дер Шерегељ, Беопресс, Београд 2014, s. 48; Д. Војак „Устај Циго, mу ти мјесто није, хај' у логоре гдје се мотком бије”, или о перцепцији Рома у Независној Држави Хрватској, 1941.-1945., w: tamże, s. 23.

N. Lengel-Krizman Prilog proučavanju..., s. 38. 
1942 roku stają przed oczami Enisa, wizje jakby ze snu, w których zdezorientowani, umęczeni ludzie niczym zjawy wysypują się z wagonów i podążają w nieznanym kierunk $u^{44}$. Temu opisowi towarzyszy odbierane przez narratora niemal sensualne wrażenie bycia otoczonym przez coś gęstego, mówi wręcz o "gęstości chwili i miejsca". Enis odczuwa unoszące się w powietrzu nieszczęście: „Czuje na plecach gęstość powietrza, które popycha sto ton nadciągającej masy" ${ }^{\prime 45}$. Doznania są potęgowane przez dźwięki: pisk i skrzypienie szyn, krzyki, szum mylonych kroków ${ }^{46}$. Jest to jeden z najbardziej dojmujących fragmentów powieści, którego potworność potęguje atmosfera zagubienia i nadciągającej katastrofy.

Auschwitz zostaje wprowadzone do powieści za sprawą dokumentów (fotografie, kartki pocztowe, różnego typu potwierdzenia i pisma), które Ramadan ocala podczas przeprawy przez Wisłę. Są one ponadto osią konstrukcyjną, która spaja współczesne wątki fabularne z tymi, które dotyczą czasów II wojny światowej. W uratowanych przez więźnia dokumentach pojawia się bowiem nazwisko Selmanić, które nosi ojciec Enisa (Fabo). Ten zbieg okoliczności pozwala ojcu głównego bohatera na snucie marzeń o spieniężeniu dowodów zbrodni. Zbieranie dokumentów związanych z ofiarami z czasów II wojny światowej staje się jego obsesją. Zakładane przyszłe bogactwo jest jednak niemożliwe, nie tylko dlatego, że w końcowych scenach książki w przypływie złości Enis niszczy papiery, ale przede wszystkim dlatego, że opowieść o cierpieniach Romów sytuuje się na obrzeżach pamięci oficjalnej, więc nie stanowi przedmiotu większego ani tym bardziej komercyjnego zainteresowania. Lujanović w osobie Fabo pośrednio nawiązuje do kategorii pamięci, która jednak tym razem sprowadza się do zabiegów mających na celu wyrównanie rachunków, tj. materialne zadośćuczynienie za krzywdy („im sprawiedliwość - jemu kasa. Jeden zmarły - jedna moneta") ${ }^{47}$.

Lujanović wskazuje w tym fragmencie dokładną, znaną z historiografii datę, a mianowicie maj 1942 roku, jako ten okres, w którym do Jasenovaca przybywali wagonami Romowie. D. Vojak Počeci progona Roma u Nezavisnoj Državi Hrvatskoj ili o inicijativi Križevaca o potrebi „odtsranjenja" Roma, w: Друга међународна конференција Холокауст над Јеврејима, Ромима и Србима у другом светском рату, red. В. Вученовић, Е. Дер Шерегељ, Беопресс, Београд 2015, s. 23; N. Lengel-Krizman, Prilog proučavanju..., s. 35.

\section{N. Lujanović Oblak boje kože, s. 37.}

Tamże, s. 37.

Tamże, s. 124. W tym kontekście nabierają znaczenia przywoływane już tutaj wydarzenia, które miały miejsce w obozie Dachau. Wówczas czternastu Sinti podjęło strajk głodowy, aby w ten sposób zaprotestować przeciw konsekwentnemu ignorowaniu (na poziomie administracyj- 


\section{Ramy Porajmosa}

Kategoria Porajmosa pojawia się w powieści na kilku poziomach. Z jednej strony odnieść ją można do drogi, jaką przechodzi Ramadan. Rozpoczyna się ona w fabryce Daimler-Benza i prowadzi przez kolejne stopnie degradacji, związane ze spadaniem w hierarchii obywateli. Końcowym przystankiem w tej wędrówce jest śmierć, która przychodzi w chwili, gdy przestaje być w obozie potrzebny. Niebagatelne znaczenie ma fakt, że Ramadan Selmany, który przed wojną pracował w fabryce samochodów, jest zdolnym mechanikiem samochodowym. Jego śmierć zostaje odroczona. Jest bowiem w obozie użyteczny, a wręcz niezbędny (jako jedyny potrafi naprawić ciężarówkę), z czego zdaje sobie sprawę w momencie, gdy - w odróżnieniu od swoich towarzyszy z Sonderkomnanda - nie trafia do komory gazowej, lecz staje się członkiem kolejnej grupy. Jego degradacja rozpoczyna się jednak znacznie wcześniej, w miejscowości Oberwart, leżącej w kraju związkowym Burgerland, we wschodniej Austrii. Możemy przypuszczać, że Lujanović nieprzypadkowo wybiera właśnie tę część Austrii na miejsce dorastania bohatera. Oberwart posłużyło kierownikowi berlińskiego Instytutu Badań nad Higieną Rasową i Biologią Populacyjną - Robertowi Ritterowi do udowodnienia tezy o niebezpieczeństwie, jakie niosą ze sobą małżeństwa mieszane (cygańsko-niemieckie). Zagrożenie dla biologicznej egzystencji Niemców widać wyraźnie w Oberwart, w którym populacja romska w ciągu nieco ponad 40 lat wzrosła $0400 \%$, a niemiecka jedynie o $20 \%{ }^{48}$. To tam ponadto - jak czytamy w powieści - już w 1928 roku wprowadzone zostają regulacje, których celem jest rejestracja i oznaczenie zamieszkujących te tereny Romów ${ }^{49}$.

W 1930 roku Ramadan zostaje zatrudniony w fabryce aut, jednak traci pracę po wprowadzeniu ustaw norymberskich. Lujanović na przykładzie bohatera wskazuje kluczowe wydarzenia z przedwojennej historii, które

nym i symbolicznym) eksterminacji Romów podczas II wojny światowej. Starania o odszkodowania niemieckich Romów i Sinti do tego czasu były całkowicie pomijane, bowiem uważano, że prześladowania Romów wynikały z pobudek społecznych, a nie rasowych. A. Mirga O godne miejsce wśród ofiar. Holokaust i eksterminacja Romów w okresie Il wojny światowej, w: Dlaczego warto uczyć o Holokauście..., s. 94-95. Lujanović nawiązując do tych wydarzeń, ale i do faktu marginalizowania ludobójstwa nad Romami podczas procesu w Norymberdze, pisze: „Ani nikt o nich nie wspomina na procesach nazistów, ani nie uznano, że popełniono nad nimi zbrodnie, nikt nie płaci im odszkodowania, ani nikt się nie zwrócił z jakimkolwiek przeprosinami". N. Lujanović Oblak boje kože, s. 126.

48 L. Mróz Niepamieć nie jest zapominaniem..., s. 97-98.

49 N. Lujanović Oblak boje kože, s. 144-145. 
konsekwentnie prowadzą do decyzji o eksterminacji Romów. Kolejnym ważnym momentem w życiu Selmany'ego jest rok 1936, kiedy to w jednym z urzędów podlegających Instytutowi Badania Higieny Rasy zostaje mu założona kartoteka oraz wytatuowany numer. Warto dodać, że zabiegi te narrator zestawia z procedurami oznaczania koni, co jednoznacznie wskazuje na sposób traktowania Romów, który zbliżony jest do obchodzenia się ze zwierzętami. W przeddzień olimpiady w Berlinie, gdy ulice miast są "czyszczone z cygańskich szczurów" ${ }^{50}$, bohater trafia do obozu pracy, w którym po raz pierwszy zdaje sobie sprawę, że może zostać bezkarnie zabity. To tam w końcu zostaje przyporządkowany do kategorii oznaczonej skrótem ZM+ (cygański mieszaniec z dominującą krwią cygańską) ${ }^{51}$, co jest równoznaczne $\mathrm{z}$ odroczoną w czasie śmiercią.

Doświadczenie schodzenia po kolejnych stopniach drabiny społecznej narrator kojarzy z niemożliwym do zaspokojenia głodem wrogów. To „ten głód ich zmuszał do produkowania/tworzenia okropności, na końcu wszystko to staje się jednym wielkim pożeraniem, porajmos, panowaniem bestii, które pożerają wszystko, co im stanie na drodze, Daimler-Benz, Auschwitz-Birkenau, tyle razy byłem przeżuty, wypluty i jeszcze raz, aż zrozumiałem, że nigdy ten głód się nie nasyci, przyjemność leży w samym pochłanianiu, siorbaniu, mlaskaniu”52. I w innym miejscu dodaje: „[...] oni są kreatorami i strażnikami fabryki śmierci, to ich zawód [...]. Dla nich ważna jest procedura, mięso jest częścią tej procedury, spalania i niszczenia, oni są bezwzględnymi profesjonalistami [...]"53. Słowa te pośrednio nawiązują do przekonania, jakoby system nazistowski stworzył doskonale działający system (fabryki śmierci), a sam proces „pozbywania się” odpadów działał w nim bez zarzutu, został bowiem oparty na racjonalnych fundamentach ${ }^{54}$. Następne miejsca, do których bohater trafia, są kolejnymi kręgami piekła. Uderzający jest fakt, że schodzenie coraz niżej powiązane jest z niewypowiedzianym przekonaniem, że jednostkę należy maksymalnie wyeksploatować

50 Tamże, s. 157.

51 Kierownik berlińskiego Instytutu Badań nad Higieną Rasową i Biologią Populacyjną Robert Ritter tak sklasyfikował Romów: Z - czystej krwi Cygan, ZM - cygański mieszaniec, ZM+ - cygański mieszaniec z dominującą krwią cygańską, ZM - cygański mieszaniec bez dominującej cygańskiej krwi, NZ - nie-Cygan. Podajemy za: J. Talewicz-Kwiatkowska Romowie i Sinti..., s. 14.

N. Lujanović Oblak boje kože, s. 167. Tamże, s. 137. 
czy też - mówiąc słowami bohatera - „przeżuć”, a następnie „wypluć”, by posłużyła jeszcze w kolejnym miejscu ${ }^{55}$. W 1942 roku Ramadan trafia ostatecznie do Auschwitz, do bloku cygańskiego IIb. W obozie bohater/narrator pracuje jako szofer ciężarówki i ta pozycja daje mu pewne przywileje. Jednak i tutaj obowiązuje swoiste prawo, wedle którego jego wartość z dnia na dzień spada. Najpierw ciężarówką przewozi dokumenty i przedmioty zagrabione więźniom do magazynu, tzw. Kanady. Następnie jego zadanie polega na dowożeniu dzieci do szpitala doktora Mengele, wożeniu chorych i umierających, potem na przewożeniu martwych i zrzucaniu ich do przygotowanych dołów mogilnych, a nawet na transportowaniu cyklonu B. Kolejny stopień wtajemniczenia związany jest z pracą w Sonderkommando, która polega na czyszczeniu komór gazowych, umieszczaniu ciał w krematoriach, a następnie na rozdrabnianiu kości na pył. W kolejno występujących po sobie etapach unicestwienia, w którym uczestniczy bohater, również dostrzec można analogię do działania wielkiego przewodu pokarmowego, w którym ważną rolę odgrywa proces „pożerania” jednostki ludzkiej i wydalania resztek, pozostałości po niej,jaką w rzeczywistości obozu stanowi popiół, który również należy zutylizować.

Ostatnie zadanie, jakie zostaje przydzielone Ramadanowi, polega na przewożeniu ciężarówką popiołu do Wisły. W opisie sposobu, w jaki popiół znika w odmętach wody, wyraźnie jest wyeksponowana semantyka pochłaniania. Zresztą kolejne etapy pozbywania się zwłok są wielokrotnie opisane za pomocą metaforyki jednoznacznie nawiązującej do procesów trawiennych. I tak najpierw mamy ogień, który pochłania ciała, i krematorium, które nie ma oczekiwanej mocy przerobowej, niczym straszny zwierz „nie może więcej przełykać, ma pełne usta" ${ }^{56}$, potem jezioro nieopodal obozu, które „dłużej nie może łykać popiołu, nasyciło się”, i w końcu Wisłę „królową bezsensu, wezbraną i sytą" czas pochłaniania popiołu jest wyraźnie personifikowana. Wisła i Ramadan próbują nie patrzeć na siebie, są bowiem przepełnieni wstydem podczas pozbywania się ludzkich prochów, „wielka wyspa z popiołu zmienia się w małe oddzielne kopce jak samotne wysepki wulkaniczne, a następnie leniwa woda

N. Lujanović Oblak boje kože, s. 168.

Tamże, s. 213.

Tamże, s. 165.

Tamże, s. 204. 
przykrywa wszystko i zaczyna trawić"59. Warto wspomnieć, że swoisty bunt przedmiotów, a przede wszystkim natury (jezioro, które nie przyjmuje już prochów), można powiązać z zakwestionowaniem dominującego wśród nazistów przekonania, że przyroda jest neutralna. Wiara w jej niewinność zostaje zderzona z jej potencjałem subwersywnym, który ujawnia się w końcowej scenie opowieści o Auschwitz, kiedy to umierający Ramadan zostaje wyciągnięty na brzeg. Śledząc odczucia płynącego z nurtem więźnia, można odnieść wrażenie, że Wisła się z nim zespala, że nie tyle nawet pomaga rannemu, ile nie przeszkadza mu w jego misji, tj. próbie uratowania dowodów zbrodni. Co więcej, zakończenie powieści sugeruje, że prawdopodobna śmierć bohatera nie poszła na marne, że w sensie symbolicznym jego ucieczka się powiodła, bowiem dowody zbrodni (wbrew staraniom nazistów) zostaną zachowane. Biorąc jednak pod uwagę nikłą obecność pamięci o romskim holokauście w latach powojennych, równie dobrze można uznać, że ofiara Ramadana została zaprzepaszczona, gdyż pamięć o romskiej zagładzie nie została - jak do tej pory - dostatecznie wyraźnie usłyszana.

\section{*⿻一从火}

Powieść Lujanovicia proponuje równoległą do powszechnie przyjętej wersję historii, która z trudnością (i wcale nie tak dawno temu) doczekała się akceptacji i uznania za równoprawną. Oblak boje kože to ciągle jeden z niewielu tekstów kultury, w którym cała uwaga zostaje poświęcona romskiej zagładzie i to tragiczne wydarzenie jawi się jako fragment wspólnej (chorwackiej, [post] jugosłowiańskiej, bałkańskiej) historii. Wielopłaszczyznowy utwór chorwackiego autora z pewnością jest jedną z najciekawszych artystycznie w ostatnich latach wizją wojny (II wojny światowej, wojny domowej w byłej Jugosławii), zarówno ze względu na walory literackie, jak i pamięć kulturową, którą w sobie zawiera, jako egzemplifikacja relacji między tekstem a społeczną pamięcią o przeszłości. Wydaje się, że zaproponowany przez Lujanovicia skomplikowany model pamięci o Porajmosie może stanowić ciekawy, inspirujący i prowokujący impuls dla kolejnych realizacji tego tematu, które za pomocą odwołań i przetworzeń w różnym stopniu i w odmiennych stylistkach będą wracać do tego pisarskiego projektu. 


\section{Abstract}

\section{Sabina Giergiel}

UNIVERSITY OF OPOLE

\section{Katarzyna Taczyńska}

UNIVERSITY OF WARSAW

Traces of the (non)Memory of Porajmos: The Cultural Map of the Romani Holocaust in Serbia and Croatia

Giergiel and Taczyńska explore the memory of the Romani Holocaust (Porajmos) in the countries of former Yugoslavia (Serbia and Croatia). The memory of Porajmos is considered here as a social and cultural construct that has a history typical for a particular country/region; however, this subject is commonly marginalized, both in historiography and in cultural texts. Giergiel and Taczyńska examine the causes of Porajmos (social group discrimination, specificity of cultural code, historical discrimination) and the reasons for the absence of memory (mute memory) of Porajmos. The overview of Porajmos research in the post-Yugoslav area and the discussion of commemorative practices related to the Romani genocide in Croatia and Serbia are also included. The central part of the article is an analysis of Nebojša Lujanovič's novel Oblak boje kože (Skin-Coloured Cloud, 2015), including its literary layer and vision of memory (using the imagery of the map). The novel exemplifies the relationship between the text and social memory.

\section{Keywords}

Porajmos, Romani extermination, social memory, cultural memory, Serbia, Croatia 